JÓZEF MARECKI OFMCAP.

\title{
PROGRAM HERALDYCZNY HENRYKA UZIEMBLY W KAPITULARZU WAWELSKIM
}

Początki Kapituly Krakowskiej sięgają zapewne XI wieku. Według L. Łętowskiego najstarszy ślad istnienia kapituły znajdujemy w informacji o przekazaniu jej dóbr w miejscowości Chropie (Kropie) przez Judytę, żonę Wladysława Hermana (1043-1102). Łętowski sugeruje również, że początkowo kanonicy prowadzili życie wspólne ${ }^{1}$. Kapituła kształtowała się na wzór istniejących już w krajach chrześcijańskich wspólnot duchownych pracujących przy światyniach (katedrach), przy których rezydował biskup. Wzorem innych posiadala zapewne swoje statuty, które regulowaly jej prawa i obowiązki. Wzorem krajów zachodnich Kapituła Krakowska wybierała już od XIII wieku kandydata na opróżniona katedrę biskupią. Pierwszym $z$ wybranych $w$ drodze wolnej elekcji był bł. Wincenty Kadlubek (1208-1218) w 1207 roku $^{2}$.

Każdy z kanoników posiadał własne mieszkanie, zaś obrady i spotkania odbywały się w kapitularzu. Kapituła posiadała swój własny budynek, zapewne drewniany, obok katedry na wzgórzu wawelskim. W jego miejsce, z fundacji Elżbiety żony księcia ziębickiego Jana, wzniesiono w latach 1417-1423 murowany dom kapitulny, przekazany wówczas na własność Kapituly Krakowskiej. Zostal on gruntownie przebudowany w latach $1486-1505$ przez ka-

* W artykule użyto nast. skrótów:

EK - Encyklopedia Katolicka KUL. T. 1-6. Lublin 1973-1993.

PSB - Polski Slownik Biografíczny. T. 1-32. Kraków 1935 - Warszawa 1990.

SPTK - Słownik Polskich Teologów Katolickich. T. 1-8. Warszawa 1981-1986.

${ }^{1}$ L. Lętowski, Katalog biskupów, prałatów i kanoników krakowskich. T. 2. Kraków 1852, s. V-VI; B. Przybyszewski, Krótki zarys dziejów diecezji krakowskiej. T. 1. Kraków 1989, s. 96; W. Abraham, Poczq̨tek biskupstwa i kapituly katedralnej w Krakowie. „Rocznik Krakowski”. T. 4: 1900, s. 194, 196-199.

${ }^{2}$ B. Przybyszewski, Krótki zarys..., t. 1, s. 96. 
nonika Jana Gosławskiego. Wówczas to zabudowania kapitulne zostały lokowane pomiędzy murem obronnym a wieżą Zegarową i kaplicą św. Mikołaja. Kolejna przebudowa miała miejsce w latach 1601-1604. Prace budowlane wykonywal wówczas murarz Matys Świętek. Od tego czasu pełni on funkcję kapitularza. Wykonano wówczas wejście do sali kapitulnej z kaplicy św. Mikołaja. W 1775 roku, z inicjatywy bpa Franciszka Potkańskiego (1753-1786), dobudowano do kapitularza pomieszczenia archiwalne i bibliotekę. Przeprowadzono także restaurację. Budynek uzyskał wówczas obecny wygląd. Sala kapitularza znajduje się na piętrze. Oświetla ją trzy okna od strony północnej. $\mathrm{Na}$ nowo restauracje przeprowadzono w latach 1896-1900 oraz w 1904 1906. W czasie późniejszej restauracji Henryk Uziembło wykonał dekorację wnętrza w stylu secesji oraz dwa obrazy: św. Stanisława Biskupa i Męczennika oraz bł. Wincentego Kadłubka ${ }^{3}$. Sprawą renowacji kapitularza zajmowała się Kapituła podczas obrad sesji jesiennej w dniu 1 października 1903 roku. Prace zlecono Henrykowi Uziembło, który ofertę wymalowania kapitularza za sumę 4000 koron złożył 3 grudnia 1903 roku, zobowiązując się zakończyć prace do dnia 1 kwietnia roku następnego. Wcześniej, jak wynika z Księgi zaliczek, wykonano nowe okna i okiennice w kapitularzu, bibliotece i archiwum, położono posadzkę, wyłożono pomieszczenie dębową boazerią oraz ukończono prace przy belkach stropowych. Prace te wykonali krakowscy stolarze Muranyi, Niedziẹlski i Sydor. Rzeźbiarz Tombiński jesienia 1903 roku wykonal ozdobne 24 konsole. Po ukończeniu tych prac H. Uziemblo przystapił do malowania wnętrza ${ }^{4}$. W okresie II wojny światowej w kapitularzu mieściła się pracownia konserwatorska. Wówczas to zniszczono niewielkie fragmenty dekoracji ściennej, które odnowiono po zakończeniu działań wojennych ${ }^{5}$.

Artysta malarz Henryk Uziembło (27 II 1879 - 3 III 1945) był jednym z twórców nowoczesnej sztuki dekoracyjnej, zajmowal się także grafiką użytkowa. Studiował w Kunstgewerbeschule w Wiedniu (1896-1901), Akademii Sztuk Pięknych w Krakowie (1902-1904) u T. Axentowicza i S. Wyspiańskiego, w Paryżu (1904-1905) oraz architekturę wnętrz w Anglii. Od 1922 roku do wybuchu wojny wykładał w Instytucie Sztuk Plastycznych w Krakowie. Projektował polichromie, witraże i mozaiki, oprawy książkowe, plakaty oraz wykonywał obrazy olejne. Do najbardziej znanych $i$ cenionych jego prac należy zaliczyć polichromię w krakowskim teatrze Bagatela, witraże

${ }^{3}$ Zabudowania Kapitulne. W: Katalog Zabytków Sztuki w Polsce. T. 4. Miasto Kraków, cz. 1. Wawel. Pod red. J. Szablowskiego. Warszawa 1965, s. 19, 21, 129-130.

${ }^{4}$ Arch. Kapitulne w Krakowie, [bez sygn.], Acta Illustrissimi Capituli Ecclesiae Cathedralis Cracoviensis. Ab Anno 1898, s. 77-78; Tamże, sygn. II. 3c-1, Ksiega zaliczek, s. 178-179, 174-175; Tamże, sygn. II. 3c-2, Ksiega zaliczek, s. 71, 79, 103, 118-119, 125;

${ }^{5}$ Relacja s. Klary Antosiewicz, Kraków, 26 XI 1996. 
i mozaiki w gmachu Izby Handlowej i Przemysłowej w Krakowie, projekt wnętrza tzw. sali muzycznej w Sanatorium Dłuskiego w Zakopanem oraz omawiany poniżej wystrój sali obrad Kapituły Krakowskiej.

Dotychczas do dekoracji ściennej, wykonanej przez Henryka Uziemblo, nie przywiązywano większej wagi. Pominięto jej dokładniejsze omówienie w Katalogu Zabytków Sztuki w Polsce ${ }^{7}$. Uznano jedynie za słuszne odnotować nazwisko autora dwóch malowideł ściennych, a mianowicie św. Stanislawa Biskupa i Męczennika oraz bł. Wincentego Kadłubka. Pominięto natomiast fryz heraldyczny biegnący piżej sufitu oraz pas sufitowy ${ }^{8}$. Trzeba dodać, że zdobnictwo ścienne w formie fryzów w zabudowaniach wawelskich miało już pewna tradycje, a najstarsze $\mathrm{z}$ zachowanych tego typu renesansowych ornamentów na I i II piętrze zamku pochodzą z I pol. XVI wieku.

W omawianym fryzie oraz pasie sufitowym artysta zawarł pewien program heraldyczny, który należy rozwiązać w oparciu o znajomość herbu papieskiego św. Piusa X i Kapituly Krakowskiej oraz herbów 65 biskupów krakowskich.

Tarcze, na których H. Uziembło umieścił herby, mają ksztalt gotycki i nazywane są niekiedy polskimi. Tarcze biskupów ozdobione są białą infułą z czerwonym podbiciem, $\mathrm{z}$ bogata, złotą $\mathrm{i}$ wysadzaną kamieniami opaska (circulum) bez taśm (vittae). Wszystkie infuły mają ten sam ksztalt. Warto tutaj zaznaczyć, że herby osób duchownych powstawały w ten sposób, że na tarczy pozostawiano herb rodowy, natomiast w miejsce klejnotu kładziono atrybuty wladzy duchownej, np. mitra, pastorał, kapelusz kardynalski, czy w przypadku papieża - tiarę. Herby w pasie sufitowym ozdobione sa, obok centralnie ułożoncj mitry, krzyżującymi się poza tarczą, wykonanymi ze złota, krzyżem i pastorałem. Herby papieża św. Piusa X, kard. Jana Puzyny i Kapituły Krakowskiej mają inną dekorację. Papieski herb umicszczony w centralnym polu sufitowym ujęty został w zloty owal, nad którym widnieje tiara z dwoma bialymi taśmami i srebrnymi krzyżującymi się kluczami. W części dolnej zaś opadają sploty sznura, zakończonego trzema frędzlami, wiążącego klucze. Herb kardynalski został skomponowany zgodnie z zasadami sztuki heraldycznej. Nad gotycką tarczą widnieje kapelusz kardynalski z 15 chwostami po obu stronach. Herb Kapituly Krakowskiej ozdobiony jest srebrną infułą biskupią z taśmami oraz wydłużonymi w stosunku do herbów biskupów srebrnym pastorałem i krzyżem.

${ }^{6}$ Wielka ilustrowana encyklopedia powszechna. T. 17. Kraków..., s. 296; Wielka encyklopedia powszechna. T. 12, Warszawa 1969, s. 23.

${ }^{7}$ Katalog zabytków...., s. 130.

${ }^{8}$ Bogata dekoracja kapitularza wymaga szerszego omówienia $z$ technikami włącznie, tutaj autor artytułu ograniczył się jedynie do tematyki heraldycznej. 
Każdą tarczę herbową oplata secesyjna dekoracja form roślinno - kwiatowych w ukladzie symetrycznym, która zarówno w pasie sufitowym jak i we fryzie ściennym powtarza się naprzemiennie.

Używane przez biskupów herby byly znakami rodowymi. Pierwszą próbę wykonania samodzielnego biskupiego znaku hcraldycznego możemy obserwować u bpa Fryderyka Jagiellończyka, który swój herb kardynalski skomponował w pięciu polach ze znaków: tzw. tarczy z opaską rakuska, Orła i Pogoni (z krzyżem Jagiellonów umieszczonym na tarczy jeźdźca) ${ }^{9}$.

Dla wyjaśnienia przynależności herbowej poszczególnych biskupów krakowskich oraz odgadnięcia programu, który zastosowal H. Uziembło rozwiązywanie kwestii należy rozpocząć od fryzu sufitowego składającego się z 11 herbów (w tym herbu św. Piusa X i herbu Kapituly Krakowskiej) a następnie przejść do fryzu biegnạcego poniżej sufitu, składającego się z 32 herbów, wśród których znajduje się herb Jelita występujący również w pasie sufitowym. Dzięki temu uzyskamy wykaz rządców diecezji krakowskiej od początków XX do XI wieku. Taki system zastosował bowiem malarz i dzięki takiemu opisowi herbów uzyskamy chronologiczną (zstępująca) kolejność biskupów krakowskich. W ten sposób bowiem postępował H. Uziembło, że poczynając od wspólczesnego sobie kard. Puzyny i postępując wstecz, kolejnym biskupom przypisywał znaki herbowe, wpierw umieszczając je dowolnie we fryzie sufitowym, a od herbu Pomian bpa Kazimierza Lubieńskiego kolejno we fryzie ściennym. Poza wspomnianym herbem Jelita artysta nie powtarzal tychże znaków jeśli kolejni biskupi pięczętowali się tymi samymi herbami, lecz przechodził do herbu następnego. To thumaczy dlaczego w poniższym artykule wykaz biskupów umieszczono w kolejności zstępującej.

Jak wspomniano wyżej $\mathrm{H}$. Uziemblo pominał w swym programie heraldycznym herby dziewięciu rządców diecezji krakowskiej, których wymieniaja cytowane wcześnicj Katalog biskupów, prałatów i kanoników krakowskich L. Lętowskiego i Herbarz polski K. Niesieckiego. Artysta pominąl następujace postacie: Prochora herbu Krucyni (†986) i Prokulfa herbu Kolumna (†996), mało udokumentowanych historycznie biskupów, zasiadających w Krakowie jeszcze przed ustanowieniem w tysięcznym roku biskupstwa. Następnie Poppona herbu Swieńczyc (†1023), Gompona herbu Radzic (†1032), Rachelina herbu Krucyni (†1046), Lamberta Zulę herbu Starża (†1071), Baldwina herbu Aichinger (†1109), Maurusa herbu Lewart (†1118), Gedkę herbu Gryf (1186) rządcę diecezji od 1166 roku oraz Fryderyka Jagielloń-

${ }^{9}$ Siegel des Mittelalters von Polen, Lithauen, Schlesien, Pommern und Prussen. Berlin 1854, tab. 15. 
czyka (27 IV 1468 - 14 III 1503) biskupa krakowskiego w latach 1489-1493 a od 1493 roku kardynała ${ }^{10}$. Artysta nie uwzględnił sufraganów i administratorów apostolskich - poza Antonim Gałeckim - dlatego też, mimo, że niektórzy $z$ nich używali występujące we fryzie herby, to jednak zostali pominięci przez autora niniejszej pracy.

Fryz sufitowy zawiera 11 herbów. Obok wspomnianego wcześniej herbu Piusa X oraz herbu Kapituły Krakowskiej i aktualnego H. Uziemble rządcy diecezji znajduje się we fryzie 8 znaków heraldycznych biskupów czasowo najbliższych autorowi. Ponieważ brak jest $w$ ich układzie ciagu chronologicznego, dlatego zostaną omówione kolejno poczynajac od strony zachodniej.

Herbem Rawicz ${ }^{11}$ pieczętowal się gorący patriota, teolog, pedagog i astronom Andrzej Gawroński (30 XI 1740 - 7 IV 1813) prekonizowany biskupem krakowskim w dniu 24 IX 1804 roku. Rzady diecezja objal dnia $5 \mathrm{~V}$ 1805 roku i sprawowal je do śmierci ${ }^{12}$.

Tego samego herbu używał bp Jan Grot ( $\dagger 5$ VIII 1347) - nazywany Grotowicem - rządca diecezji krakowskiej w latach 1326-1347, który dał się poznać jako dbaly o świątynię katedralną duszpasterz i obrońca niezależności diecezji od władzy świeckiej ${ }^{13}$.

Kolejnym jest herb Herburt ${ }^{14}$, zwanego niekiedy Pawęża, używał Jan Pawel Woronicz (3 VII 1757 - 4 XII 1829). Biskupem krakowskim zostal prekonizowany w dniu 18 XII 1815 roku przy poparciu cara Aleksandra I (1801-1825). Sakre przyjał w Warszawie w dniu 8 V 1816 roku. W dwa lata później diecezja krakowska została wyłączona z metropolii gnieźnieńskiej i włączona do warszawskiej. W dniu 28 I 1828 roku bp Woronicz zostal przeniesiony do Warszawy, gdzie otrzymal stolice arcybiskupia i prymasostwo Królestwa Polskiego. Pisarz, pocta i mówca. Zmarl w Wiedniu ${ }^{15}$.

${ }^{10}$ K. Niesiecki, Herbarz polski. T. 1 Lipsk 1839-1846, s. 32-33; B. Przybyszewski, Krótki zarys..., t. 1. Kraków 1989, s. 94.

${ }^{11} \mathrm{~W}$ polu zlotym panna $\mathrm{z}$ rozpuszczonymi włosami, w koronie i rozłożonymi rękoma na niedźwiedziu srebrnym (wł. czarnym) kroczacym w lewo (wł. w prawo). - S. Górzyński, J. Kochanowski, Herby szlachty polskiej. Warszawa 1990, s. 135; J. Szymański, Herbarz średniowiecznego rycerstwa polskiego. Warszawa 1993, s. 249.

${ }^{12}$ L. Lętowski, Katalog..., t. 2, s. 258-264; J. Poplatek, Gawroński Andrzej. W: PSB, t. 7, s. 323-324; P. Nitecki, Biskupi Kościola w Polsce. Warszawa 1992, s. 63.

${ }^{13}$ L. Łętowski, Katalog..., t. 1, s. 247-260; A. Matuszek, Grot (Grotowic) Jan. W: PSB, t. 9, s. 15-18, P. Nitecki, Biskupi..., s. 73.

${ }^{14} \mathrm{~W}$ polu czerwonym trzy złote (wł. srebrne) miecze przeszywające $\mathrm{W}$ gwiazde złote jabłko. - S. Górzyński, J. Kochanowski, Herby ..., s. 64; J. Szymański, Herbarz ..., s. 135.

${ }^{15}$ L. Lętowski, Katalog..., t. 2, s. 264-271; P. Nitecki, Biskupi..., s. 229; M. D. Kowalski, Pralaci..., s. 173-174. 
Trzecim z kolei jest herb Soltyk ${ }^{16}$. Jest to rodowy herb gorliwego duszpasterza i patrioty Kajetana Ignacego Soltyka (12 XI 1715 - 30 VII 1788) ordynariusza krakowskiego w latach 1759-1788, deportowanego przez Rosjan w gląb Rosji $(1767-1773)^{17}$.

W polu czwartym od zachodu artysta umieścil herb Sas ${ }^{18}$. Znakiem tym posługiwał się kard. Albin Dunajewski (1 III 1817 - 18 VI 1894), w młodości więzien ,za sprawę narodową", który po amnestii cesarskiej obrał stan duchowny. W dniu 21 IV 1879 roku zostal nominowany na stanowisko biskupa krakowskiego, sakrę otrzymał w dniu 8 VI 1879 roku. Odrodził diecezję, podniósł poziom kleru, wspieral działalność charytatywną i naukową. W 1889 roku otrzymal od cesarza tytuł książęcy, a w dniu 23 VI 1890 roku zostal mianowany przez Leona XIII (1878-1903) kardynałem ${ }^{19}$.

Kolejny herb, zwany Oginiec ${ }^{20}$, używał kard. Jan Puzyna (13 IX 1842 8 IX 1911), wpierw sufragan lwowski (1886), a od dnia 7 X 1894 roku, na podstawie cesarskiej nominacji, mianowany ordynariuszem krakowskim. Dnia 17 II 1895 roku odbyl ingres do katedry wawelskiej. W dniu 15 IV 1901 zostal mianowany przez Leona XIII (1879-1903) kardynałem-prezbiterem Santi Vitalis, Gervassi et Protasii ${ }^{21}$.

Centralne pole fryzu sufitowego zdobi herb papicża Piusa $X^{22}$ (2 VI 1835 - 20 VIII 1914). Józef Sarto, bo takie było imię i nazwisko późniejszego papieża, w 1884 roku zostal biskupem Mantui, w 1893 roku patriarchą Wenecji a w dniu 4 VIII 1903 roku papieżem. Przeprowadził szereg reform liturgicz-

${ }^{16}$ Orzel czarny obrócony w prawo, ze skrzydlami do góry, wspięty, mający koronę złotą na szyi i rękę ludzką zbrojną z pałaszem między prawym skrzydłem a szyją wychodząca wzniesioną ponad glowę jakby do cięcia. - Polska encyklopedia szlachecka. T. 11. Warszawa 1938 , s. 126-127, 337 .

${ }^{17}$ L. Lętowski, Katalog..., t. 2, s. 242-257; P. Nitecki, Biskupi..., s. 192.

${ }^{18} \mathrm{~W}$ polu blękitnym nad złotym księżycem, między takimi samymi dwoma gwiazdami sześciopromiennymi, złota (wł.srebrna) strzała. - A. Boniecki, Herbarz Polski. T. 5. Warszawa 1902, s. 85-86; S. Górzyński, J. Kochanowski, Herby ..., s. 139; J. Szymański, Herbarz ..., s. 256.

${ }^{19}$ T. Glemma, M. Tyrowicz, Dunajewski Albin. W: PSB, t. 5, s. 462-465; S. Janaczek, Dunajewski Albin. W: EK, t. 4, k. 348-349; P. Nitecki, Biskupi..., s. 52.

${ }^{20} \mathrm{~W}$ polu blękitnym na barku czerwonej klamry krzyż srebrny u góry rozszczepiony. Polska encyklopedia szlachecka. T. 2. Warszawa 1935, s. 54; t. 3, s. 425.

${ }^{21}$ J. Kracik, Puzyna Jan Duklan Maurycy Pawel.W: PSB, t. 29, s. 488-491; P. Nitecki, Biskupi..., s. 174; ; M. Rogucki, J. Zalewski, Rody szlachty polskiej. Warszawa 1993, s. 124.

${ }^{22} \mathrm{Na}$ tarczy podzielonej w pas w części górnej uskrzydlony lew, tzw. wenecki, opierający łapc na ksiazzce z napisem o nieczytelnym napisie rozpoczynającym się od słów pax tibi, w pasie dolnym na skalistym dnie morza leżąca kotwica, nad którą sześcioramienna gwiazda. Herb nawiazuje do patriarszej stolicy kard. Sarto w Wenecji. 
nych, propagował zdrową pobożność, popierał organizacje katolickie, zwalczał modernizm, zreformował Kurię Rzymską. W 1954 roku został kanonizowany $^{23}$.

W polu następnym, przesuwając się w kierunku wschodnim, H. Uziembło umieścił herb kapituły krakowskiej przedstawiający na błękitnej tarczy trzy zlote korony. Według L. Lętowskiego Aron pieczętowat się trzema koronami złotemi w polu bialem, dwie u góry a jedna u spodu, które wzięla kapituła po nim, za herb sobie $e^{24}$. Bp Aron ( $\dagger 9$ X (lub $\left.15 \mathrm{~V}\right) 1059$ ) pochodził z obszaru języka niemieckiego. Jako opat tyniecki (co podważają niektórzy historycy) był wspólpracownikiem Kazimierza Odnowiciela (1016-1058), z inicjatywy którego został prawdopodobnie biskupem w 1064 roku. Wedlug niektórych źródeł posiadal przywilej paliusza, a tym samym prawo konsekrowania biskupów. Przywileje te byly potrzebne, gdyż miał restaurować wiarę chrześcijańską w Polsce. Był propagatorem wspólnego życia kleru w formie wspólnot kanonickich, m.in. wprowadzil dla kanoników wawelskich obowiązek wspólnego odmawiania brewiarza. Nawiązał kontakty umysłowe i kulturalne $z$ ośrodkami zachodnimi ${ }^{25}$.

Kolejnym jest herb Rogala ${ }^{26}$. Jest to herb Feliksa Rogala Turskiego (14 I 1729 - 31 III 1800), który kolejno był biskupem chelmskim (1765), łuckim (1771) i krakowskim (1790-1800). Mocno angażował się w sprawy polityczne, m.in. odbierał od króla Stanisława Augusta Poniatowskiego (17641795) przysiegę na wierność Konstytucji $3 \mathrm{Maja}^{27}$.

Herb Jelita ${ }^{28}$, który zostanie powtórzony we fryzie ściennym, przynależy do Karola Skórkowskiego - wpierw administrator diecezji krakowskiej (18281829) - a po przyjęciu sakry biskupiej w dniu 24 I 1830 roku jej ordynariusz. Za udzielenie poparcia Powstaniu Listopadowemu został w 1835 roku przez zaborców usunięty z Krakowa. Aż do śmierci (25 I 1851) rezydował w Opawie na Sląsku ${ }^{29}$.

${ }^{23}$ H. Stadler, Leksykon papieży i soborów. Warszawa 1992, s. 259-261 (tamże reprodukcja herbu papieskiego).

${ }^{24}$ L. Lętowski, Katalog..., t. 1, s. 21.

${ }^{25}$ L. Lętowski, Katalog..., t. 1, s. 20-26; M. Bałaban, Aron. W: PSB, t. 1, s. 165-166; A. Witkowska, Aron. W: EK, t. 1, k. 947-948; P. Nitecki, Biskupi..., s. 22; B. Kwiatkowska - Baster, Z. K. Baster, Tyniec u progu tysiq̨clecia. Kraków 1994, s. 29.

${ }^{26}$ Tarcza dwudziclna w słup, w polu prawym czerwonym srebrny róg jeleni o czterech porostach, w polu lewym srebrnym czerwony róg bawoli - w pasie inne kolory. - S. Górzyński, J. Kochanowski, Herby ..., s. 137; J. Szymański, Herbarz ..., s. 251-252.

${ }^{27}$ L. Eętowski, Katalog..., t. 2, s. 257-258; Polska encyklopedia szlachecka. T. 12. Warszawa 1938, s. 35; P. Nitecki, Biskupi..., s. 212.

${ }^{28} \mathrm{~W}$ polu czerwonym trzy skrzyżowane złote kopie. - S. Górzyński, J. Kochanowski, Herby ..., s. 71; J. Szymański, Herbarz ..., s. 143-144.

${ }^{29}$ L. Lętowski, Katalog..., t. 2, s. 271-272; P. Nitecki, Biskupi..., s. 190. 
Następny herb, zwany Junosza ${ }^{3 \tilde{}}$, używał Antoni Gałecki (1811 - 10 III 1885), który w dniu 19 IX 1862 roku został konsekrowany biskupem i mianowany wikariuszem apostolskim, a w cztery dni później zostal prekonizowany administratorem diecezji krakowskiej. Lojalny wobec władz austriackich, niechętnie postrzegany przez duchowieństwo złożył urząd w 1879 roku i wyjechal do Wiednia ${ }^{31}$.

Wcześniej herbem tym pieczętowali się trzej biskupi krakowscy. Jakub Zadzik (1582 - 17 III 1642), biskup krakowski od 1635 roku. Zanim został rządcą diecezji krakowskiej byl sekretarzem królewskim i koronnym, od 1624 roku biskupem chelmińskim i pomezańskim. Dał się poznać jako dyplomata i polityk ${ }^{32}$. Felicjan Konstanty Szaniawski (24 XI 1668 - 2 VII 1732), który wpierw pełnił obowiązki zarządcy diecezji kujawsko - pomorskiej, a od dnia 3 VII 1720 roku ordynariusza krakowskiego. Pozostawil po sobie pamięć pobożnego i gorliwego kapłana. Erygował dla diecezji krakowskiej seminaria w Krakowie i Kielcach ${ }^{33}$. Andrzej Stanisław Kostka Załuski (2 XII 1695 - 16 XII 1758 - kolejno rządca diecezji płockiej, łuckiej, chełmińskiej, administrator diecezji pomezańskiej a w końcu ordynariusz krakowski od dnia 2 V 1746 roku. Był jednym ze współzałożycieli biblioteki, która od jego nazwiska przyjęła nazwę „Załuskich"34.

Ostatnim herbem $w$ pasie herbowym umieszczony na suficie jest herb Grabie $^{35}$, rodowy znak Lipskich. Kard. Jan Aleksander Lipski (1690 - 20 II 1746) był prepozytem bożogrobców w Miechowie i równocześnie ordynariuszem łuckim od 1731 roku, następnie krakowskim - z nominacji królewskiej, co potwierdzila Stolica Apostolska w dniu 19 XII 1732 roku. Pozostal w pamięci jako stronnik Sasów, m.in. koronował Augusta III (1733-1763), mecenas kultury i uczącej się młodzieży. Przyczynił się do modernizacji wnętrza katedry wawelskiej ${ }^{36}$.

Herbem Grabie pieczętował șię także Andrzej Lipski (1572 - 4 IX 1631), pochodzący $z$ rodziny protestanckiej. Po śmierci bpa Tylickiego (†13 VII

${ }^{30} \mathrm{~W}$ polu czerwonym kroczący baran srebrny w prawo. Por. S. Górzyński, J. Kochanowski, Herby..., s. 75; J. Szymański, Herbarz..., s. 146.

${ }^{31}$ T. Glemma, Galecki Antoni. W: PSB, t. 7, s. 240-241; J. Kracik, Galecki Antoni. W: EK, t. 5, k. 844-845; P. Nitecki, Biskupi..., s. 62.

${ }^{32}$ L. Lętowski, Katalog.., t. 2, s. 194-204; P. Nitecki, Biskupi..., s. 232.

${ }^{33}$ L. Lętowski, Katalog..., t. 2, s. 230-234; P. Nitecki, Biskupi..., s. 199.

${ }^{34}$ L. Łętowski, Katalog..., t. 2, s. 2378-242; J. Wysocki, Zaluski Andrzej Stanistaw. W: SPTK, t. 4, s. 514-516; P. Nitecki, Biskupi..., s. 233.

${ }^{35} \mathrm{~W}$ polu złotym na srebrnej (wł. zielonej) murawie grabie srebrne o siedmiu zębach w słup. - S. Górzyński, J. Kochanowski, Herby..., s. 59; J. Szymański, Herbarz..., s. 128

${ }^{36}$ L. Eętowski, Katalog..., t. 2, s. 234-237; B. Brzuszek, Lipski Jan Aleksander. W: SPTK, t. 2, s. 534-536; P. Nitecki..., Biskupi..., s. 124. 
1616) wybrany został przez Kapitułę Krakowską administratorem diecezji. W następnym roku przeszedł na biskupstwo łuckie, następnie włocławskie (1623), a od dnia 2 XII 1630 roku krakowskie ${ }^{37}$.

Starszymi, chronologicznie, sa właściciele herbów umieszczonych we fryzie ściennym. Dla uzyskania właściwej kolejności zstępujacej aby kontynuować ciąg zapoczątkowany $w$ pasie sufitowym, opis należy rozpoczać od ściany wschodnicj, na której $\mathrm{H}$. Uziembło umieścił 5 herbów. Zostaną omówione kolejno poczynając od strony północnej.

Herb Pomian ${ }^{38}$ jest rodowym znakiem Kazimierza Lubieńskiego (1652 11 V 1719). Po śmierci bpa Dabskiego ( $† 15$ XII 1700) pełnił obowiązi administratora diecezji krakowskiej. We wrześniu tego roku mianowany sufragancm krakowskim, sakrę przyjałł w dniu 6 III 1701 roku na Jasnej Górze. Od dnia 14 XII 1705 roku rządca diecezji chełmskiej i równocześnie opat komendatoryjny w Czerwińsku. W 1709 roku nominowany na biskupstwo krakowskie, ingres do katedry wawelskiej odbył w dniu 15 III 1711 roku. Dał się poznać na polu dzialalności charytatywnej oraz jako propagator kultu maryjnego, m.in. koronował obraz MB Częstochowskiej (1717). Restaurował i uposażał kościoły, odbudował wieżę zegarową przy katedrze wawelskiej. Podniósł dyscyplinę wśród kleru i ufundowal seminarium w Lublinie. Ustanowił stypendia dla ubogiej młodzieży i kleryków oraz przyczynił się do wzniesienia mauzoleum św. Jana Kantego w kościele św. Anny w Krakowie ${ }^{39}$.

Użytkownikiem następnego herbu zwanego Denhoff, lub rzadziej Świn$\mathrm{ka}^{40}$ był Jerzy Olbracht Denhoff (7 IV 1640 - 16 III 1702), który zanim otrzymał święcenia biskupie zajmowal różne stanowiska kościelne oraz społeczne. Kolejno był rządcą diec. kamienieckiej (1686), następnie przemyskiej (1689), a krótko przed śmiercią został przeniesiony do Krakowa (9 X 1701) ${ }^{41}$.

Herb środkowy na ścianie wschodniej, o nazwie Godziemba ${ }^{42}$, jest znakiem Stanisława Kazimierza Dąmbskiego (ok. 1638 - 15 XII 1700), sekreta-

${ }^{37}$ L. Lętowski, Katalog..., t. 2, s. 177-186; E. Ozorowski, Lipski Andrzej. SPTK, W: t. 2, s. 536-537; P. Nitecki, Biskupi..., s. 124.

${ }^{38} \mathrm{~W}$ polu czerwonym (wl. zlotym) żubrza glowa srebrna (wł. czarna) na wprost przeszyta od góry mieczem w lewo (wł. w prawo) skos. - S. Górzyński, J. Kochanowski, Herby..., s. 123; J. Szymański, Herbarz..., s. 229-230.

${ }^{39}$ L. Lętowski, Katalog..., t. 2, s. 227-230; J. Gierowski, Lubieński Kazimierz. W: PSB, t. 18, s. 487-489; P. Nitecki, Biskupi..., s. 130.

${ }^{40} \mathrm{~W}$ polu czerwonym glowa dzika czarna (we fryzie srebrna) w prawo. - A. Boniecki, Herbarz polski. T. 4. Warszawa 1901, s. 250, 252;

${ }^{41}$ L. Lętowski, Katalog..., t. 2, s. 224-227; S. Olczak, Denhoff Jerzy Albrecht. W: EK, t. 3, k. 1169; P. Nitecki, Biskupi..., s. 48; M. Rogucki, J. Zalewski, Rody szlachty .., s. 42.

${ }^{42} \mathrm{~W}$ polu czerwonym sosna barwy naturalnej o trzech konarach i pięciu korzeniach. S. Górzyński, J. Kochanowski, Herby..., s. 57; J. Szymański, Herbarz..., s. 124-125. 
rza króla Michała Korybuta Wiśniowieckiego i aktywnego polityka. Jako biskup zasiadał na pięciu stolicach: od 1673 roku rządca diecezji chełmskiej, od 1676 luckiej, od 1680 płockiej, od 1691 kujawsko-pomorskiej, a od 1700 krakowskiej. Zmarł przed objęciem biskupstwa i zostal pogrzebany - jako dobrodziej jezuitów - w kościele p.w. św. św. Piotra i Pawla w Krakowie ${ }^{43}$.

Kolejny, którym pieczętowali się Jan Małachowski i Piotr Gembicki, to herb Nalęcz ${ }^{44}$. Jan Małachowski (1623 - 20 VIII 1699) stan duchowny obrał po śmicrci żony. Podczas najazdu szwedzkiego towarzyszył Janowi Kazimierzowi (1648-1668) w ucieczce na Śląsk za co otrzymal opactwo komendatoryjne $\mathrm{w}$ Mogilnie i stanowisko referendarza koronnego. Dyplomata i posel królewski, zarządca dochodów Marii Ludwiki (1611-1667) i egzekutor jej testamentu. Zaufany króla Michała Korybuta Wiśniowieckiego (1669-1673) a następnie króla Jana III Sobieskiego (1674-1696), z nominacji którego został biskupem chelmińskim (1676) i administratorem diecezji pomezańskiej, a od dnia $12 \mathrm{~V} 1681$ roku biskupem krakowskim. Troszczyl się o rozwój powołań kapłańskich i przyczynił się do wyniesienia na oltarze bł. Kingi ${ }^{45}$.

Piotr Gembicki (10 X 1585 - 14 VII 1657) pelnił wiele funkcji państwowych i kościelnych m.in. był opatem komendatoryjny w Tyńcu i na Świętym Krzyżu oraz proboszczem miechowskim i dwukrotnym administratorem diecezji krakowskiej $(1630,1631)$. W 1635 roku został mianowany biskupem przemyskim a od 1642 roku krakowskim. Rządy diecezją rozpoczał od zwołania synodu. Pobożny, dbaly o karność duchowieństwa, protektor zakonów ${ }^{46}$.

Ostatnim w omawianym pasie jest herb Labędź ${ }^{47}$. Jest rodowy znak Andrzeja Trzebickiego (23 XI 1607 - 28 XII 1679). Jak większość rządców diecezji tego okresu pozostawał poczatkowo w służbie królewskiej i posiadal wiele stanowisk kościelnych. W 1654 roku został mianowany biskupem przemyskim, a w cztery lata później (25 II 1658) krakowskim. Był gorliwym duszpasterzem, przeprowadził wizytacje diecezji i popicrał budownictwo sakralne ${ }^{48}$.

${ }^{43}$ L. Lętowski, Katalog..., t. 2, s. 220-224; K. Piwarski, Sabski Stanislaw. W: PSB, t. 2, s. 36-38; J. Bazydło, Dabski Stanislaw Kazimierz. W: EK, t. 3, k. 1068; P. Nitecki, Biskupi..., s. 46.

${ }^{44} \mathrm{~W}$ polu czerwonym chusta srebrna w krąg zawiązana u dolu. - S. Gorrzyński, J. Kochanowski, Herby..., s. 104; J. Szymański, Herbarz..., s. 192-193.

${ }^{45}$ L. Lętowski, Katalog..., t. 2, s. 216-220; H. E. Wyczawski, Małachowski Jan. W: $P S B$, t. 19, s. 396-398; P. Nitecki, Biskupi..., s. 135.

${ }^{46}$ L. Lętowski, Katalog..., t. 2, s. 204-208; H. Borcz, Gembicki Piotr. W: EK, t. 5, s. 935; P. Nitecki, Biskupi..., s. 64

${ }^{47} \mathrm{~W}$ polu czerwonym kroczący w lewo (wl. w prawo) łabędź srebrny kroczący z dziobem czarnym i takimiż nogami. - S. Górzyński, J. Kochanowski, Herby..., s. 99; J. Szymański, Herbarz..., s. 182-183.

${ }^{48}$ L. Lętowski, Katalog..., t. 2, s. 208-216; P. Nitecki, Biskupi ..., s. 211. 
Na ścianie południowej, analogicznie do północnej, artysta umieścił 11 herbów. Patrzac od strony wschodniej dostrzegamy herb Korab ${ }^{49}$, którym sygnowało się trzech biskupów krakowskich: Jakub Zadzik, Jan Radlica i Robert.

Jakub Zadzik (1582 - 17 III 1642) znany jest jako wspólpracownik Zygmunta III Wazy (1587-1632) i Władysława IV (1632-1648), dyplomata, posel i sekretarz królewski oraz sekretarz wielki koronny. Od 1624 roku był biskupem chelmińskim i administratorem apostolskim diecezji pomezańskiej, a od dnia 17 IX 1635 roku ordynariuszem krakowskim. Znany z hojności, lożył na kanonizację św. Jana Kantego. Ufundował kościół św. Józefa i klasztor bernardynek w Krakowie oraz dokonał restauracji kościoła św. Michała na wzgórzu wawelskim. Zlikwidował główną siedzibę arian w Rakowie ${ }^{50}$.

Jan z Radliczyc (†12 I 1392), z wykształcenia teolog i lekarz, biskupem krakowskim wybrany został przez kapitułę w dniu 2 II 1382 roku. W 1382 roku brał udział w królewskiej fundacji klasztoru paulinów w Częstochowie. Stronnik Władyslawa Jagiełly (1386-1434), w 1384 roku witał wraz z innymi królewnę Jadwigę (1384-1399) przybyła do Krakowa z Węgier, a w dniu 16 $\mathrm{X} 1384$ roku asystowal przy jej koronacji. Gorliwie sprawowal rządy w diecezji, dbał o dobra ziemskie i dochody biskupstwa. Przyczynił się do fundacji kościola p.w. Wszystkich Świętych i świątyni benedyktynów obrządku słowiańskiego w Krakowie ${ }^{51}$.

Robert, zwany Rupertem ( $\uparrow 11$ IV 1144) byl początkowo rządcą diecezji wroclawskicj (1126/1127-1142). Na stolicę krakowską został przeniesiony na prośbę księcia Władysława II Wygnańca (1138-1159) przez Innocentego III (1130-1143). Była to pierwsza zmiana biskupa z jednej stolicy na druga na ziemiach polskich. Ukończyl budowę katedry romańskiej na Wawelu, którą to budowę rozpocząl bp Maurus (1110-1117). Konsekrował ją p.w. św. Waclawa w dniu 20 IV 1142 roku. Dążył do zjednoczenia kraju. Należy dodać, że przejście bpa Roberta $z$ Wroclawia do Krakowa spotkalo się ze sprzeciwem metropolity Jakuba ze Żnina (†1148), który uważal ten fakt za złamanie kanonów ${ }^{52}$.

${ }^{49} \mathrm{~W}$ polu czerwonym korab złoty z wieżą złotą, murowaną i blankowaną. - S. Górzyński, J. Kochanowski, Herby..., s. 79; J. Szymański, Herbarz..., s. 154.

${ }^{50}$ L. Letowski, Katalog..., t. 2, s. 194-204; P. Nitecki, Biskupi..., s. 232; M. D. Kowalski, Pralaci..., s. 184-185.

${ }^{51}$ L. Lętowski, Katalog..., t. 1, s. 297-309; A. Strzelecka, Jan z Radolina. W: PSB, t. 10, s. 469-472; P. Nitecki, Biskupi..., s. 90.

${ }^{52}$ L. Lętowski, Katalog ..., t. 1, s. 58-62; K. Ożóg, Robert. W: PSB, t. 31, s. 327-328; Nitecki, Biskupi..., s. 178 . 
Nastepnym herbem jest Waza ${ }^{53}$ - rodowy herb kard. Jana Olbrachta Wazy (25 VI 1612 - 29 XII 1634), który rządca diccezji warmińskiej i administratorem apostolskim diecezji sambijskiej zostal w wieku dziewiętnastu lat. W dniu 22 II 1633 roku objał biskupstwo krakowskie. W 1629 roku zostal wyniesiony do godności kardynalskiej tytułu Sanctae Mariae in Aquiro ${ }^{54}$.

W dalszej kolejności znajduje się herb Ostoja zwany niekiedy Przeginia $^{55}$, który jest zbliżony do herbu Czcwoja ${ }^{55}$. Herb ten używał za swój znak Marcin Szyszkowski (1554 - 30 IV 1630), od 1603 roku koadiutor bpa Stanisława Gomolińskiego (1600-1604) w Łucku, a następnie rządca tejże diecezji. W trzy lata później przeniesiony na biskupstwo płockie, a w dniu $17 \mathrm{X}$ 1616 roku mianowany biskupem krakowskim. Znany jako autor polemicznych rozpraw teologicznych, przyjaciel jezuitów, przeciwnik reformacji ${ }^{57}$.

Herb Ostoja jest podobny do herbu Cholewa ${ }^{58}$, który przypisywany jest Mateuszowi ( $\dagger 18$ X 1166), biskupowi krakowskiemu w latach 1143/11441166. Opinie o jego życiu i dzialalności są podzielone. Według J. Dlugosza (1415-1480) opinia ta jest ujemna, natomiast wedlug kronikarza mistrza Wincentego (1150-1223) jest pozytywna. Prawdopodobnie był wykształcony i zasłużył się jako oddany duszpasterz. Prowadził wykwintne życie. Interesowal się działalnością misyjną na Rusi, przyjaźnił się z wroclawskim biskupem a następnie arcybiskupem gnieźnieńskim Janikiem (†1167) i Piotrem Włostowicem (1100-1153). Biskupowi Mateuszowi przypisuje się trzy pierwsze księgi „Kroniki” Wincentego Kadlubka ${ }^{59}$.

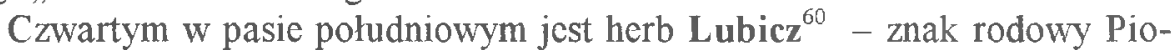
tra Tylickiego (1543 - 13 VII 1616). Zanim w 1595 roku otrzymal sakrę biskupia, zasiadal w 6 kanoniach, piastowal tytul proboszcza w Małogoszczy i prcpozyta gnieźnieńskiego oraz pelnił różne urzędy na dworze królewskim

${ }^{53}$ W polu srebrnym snop zboża w słup.

${ }^{54}$ L. Lętowski, Katalog..., t. 2, s. 186-194; T. Nowak, Jan Albert (Olbracht, Wojciech) Waza. W: PSB, t. 10, s. 422-423; P. Nitecki, Biskupi..., s. 218,

${ }^{55} \mathrm{~W}$ polu czerwonym między dwoma półksiężycami złotymi barkami ku sobie w słup miecz srebrny na opak w slup. -- S. Górzyński, J. Kochanowski, Herby..., s. 116; J. Szymański, Herbarz..., s. 214.

${ }^{56} \mathrm{~W}$ polu czerwonym między dwoma podkowami srebrnymi barkami ku sobie krzyż srebrny. - S. Górzyński, J. Kochanowski, Herby..., s. 47; J. Szymański, Herbarz ..., s. 103.

${ }^{57}$ L. Lętowski, Katalog..., t. 2, s. 170-177; E. Ozorowski, Szyszkowski Marcin. W: SPTK, t. 4, s. 296-298; P. Nitecki, Biskupi..., s. 203.

${ }^{58} \mathrm{~W}$ polu czerwonym miecz srebrny luzem ostrzem w dół między dwoma klamrami odwróconych do siebie barkami.

${ }^{59}$ L. Letowski, Katalog.., t. 1, s. 62-68; P. Nitecki, Biskupi.., s. 138.

${ }^{60} \mathrm{~W}$ polu czerwonym (wł. błękitnym, bardzo rzadko czerwonym) srebrna podkowa z takim samym krzyżem kawalerskim zaćwieczonym i takim samym krzyżem luzem w środku. - S. Górzyński, J. Kochanowski, Herby..., s. 96; J. Szymański, Herbarz..., s. 180. 
Zygmunta III Wazy (1587-1632). Kolejno był rządca diecezji chełmińskiej (1595), warmińskiej (1600), kujawsko - pomorskiej (1604) i krakowskiej (od 15 I 1607). Zwolennik Soboru Trydenckiego (1545-1563) dażący do podniesienia poziomu wiedzy i dyscypliny wśród kleru ${ }^{61}$.

Dwóch krakowskich biskupów: Bernard Maciejowski i Samuel Maciejowski pieczętowało się herbem Ciolek ${ }^{62}$. Bernard Maciejowski (1548 - 19 I 1608), początkowo administrator (od 1586) diecezji łuckiej, sakrę przyjąl dnia 24 I 1588 roku. Następnic biskup wileński (1597) - odrzucony przez kapitułę, potem krakowski (23 V 1600 - 31 VI 1606) i gnieźnieński. W dniu 17 IX 1603 roku mianowany kardynałem Sanctae Joannis ante Portam Latinam. Wspólpracownik króla Zygmunta III Wazy (1587-1632), wspóltwórca Unii Brzeskiej. Zwolennik reform trydenckich, restaurator katedry wawelskiej, propagator kultu Matki Bożej. W 1602 roku erygowal w Krakowie seminarium duchowne ${ }^{63}$.

Samuel Maciejowski ( $† 25$ X 1550), kolejno byl biskupem chelmskim (od 17 X 1539), płockim (od 22 VIII 1541) i krakowskim (od 15 X 1545) - wybrany przez kapitulę krakowską. Ingres do katedry odbył dnia 4 IV 1546 roku. Znawca klasycznej laciny. Jako mecenas sztuki skupil wokół siebie, w swym podkrakowskim białoprądnickim dworku, humanistów. Polityczny przeciwnik królowej Bony (1494-1557) ${ }^{64}$.

W środku omawianego pasa znajduje się herb Trąby ${ }^{65}$ - rodowy znak kard. Jerzego Radziwilła (31 V 1556 - 23 I 1600). Wychowywał się w rodzinie protestanckiej, lecz pod wpływem jezuitów przeszedł na katolicyzm w 1574 roku. W tym samym roku został mianowany koadiutorem bpa wileńskiego Waleriana Protasiewicza (10 IV 1556 - 31 XII 1579). W 1581 roku objał osobiste rzady w diecezji wileńskiej. Święcenia kapłańskic i sakrę biskupia przyjął dwa lata później, a w 1585 roku został mianowany kardynałem prezbiterem Sancti Sixti. W dniu 9 X 1591 roku zostal przeniesiony na biskupstwo krakowskie po kanonicznej elekcji kapituły krakowskiej. Gorliwy, dobry administrator, przeciwnik innowierców. Stronnik i doradca króla Zygmunta III Wazy (1587-1632), polityk. Dla wzmocnienia katolicyzmu zwoły-

${ }^{61}$ L. Łętowski, Katalog..., t. 2, s. 162-170; P. Nitecki, Biskupi..., s. 212.

${ }^{62} \mathrm{~W}$ polu srebrnym wól czerwony w lewo (wł. w prawo). - S. Górzyński, J. Kochanowski, Herby..., s. 46; J. Szymański, Herbarz..., s. 100-101.

${ }^{63}$ L. Lętowski, Katalog..., t. 2, s. 152-162; J. Dzięgielewski i J. Maciszewski, Maciejowski Bernard. W: PSB, t. 19, s. 48-52; P. Nitecki, Biskupi..., s. 133.

${ }^{64}$ L. Lętowski, Katalog..., t. 2, s. 117-124; W. Dworzaczek, Maciejowski Samuel. W: PSB, t. 19, s. 64-69; P. Nitecki, Biskupi..., s. 133.

${ }^{65} \mathrm{~W}$ polu srebrnym trzy trąby czarne złączone ustnikami, z czterema sztrefami złotymi i z zawiniętymi sznurami. - S. Górzyński, J. Kochanowski, Herby..., s. 154; J. Szymański, Herbarz..., s. 279-280. 
wał w Krakowie trzykrotnie synody $(1593,1594,1597)$, przeprowadzil wizytacje parafii i klasztorów, wprowadzal reformy trydenckie ${ }^{66}$.

Kolejnym herbem jest Jastrzębiec ${ }^{67}$. Herbem tym posługiwal się Piotr Myszkowski (ok. 1510 - 5 IV 1591), uczony i czolowy humanista XVI wieku. Posiadal liczne stanowiska państwowe i funkcje kościelne, m.in. w 1545 roku pelnił obowiązki wikariusza generalnego diecezji krakowskiej. W 1565 roku prekonizowany biskupem i koadiutorem bpa plockiego Andrzeja Noskowskiego (1546-1567). Biskupstwo plockie objął w 1570 roku. W 1577 roku wybrany biskupem krakowskim przez kapitułe po uprzednim wyznaczeniu go na to stanowisko przez króla Stefana Batorego (1575-1586). Uroczystego wjazdu do katedry wawelskiej dokonał 18 XII 1577 roku $^{68}$.

Tego samego herbu używal Wojcicch Jastrzębiec (ok. 1362 - 2 IX 1436). Związany był $\mathrm{z}$ dworem królewskim jako kanclerz koronny (1412) a wcześniej kanclerz i współpracownik królowej Jadwigi (1384-1399). Pozostawił po sobie pamięć zdolnego i aktywnego dyplomaty. Zasiadał w kilku kapitulach, był rządca diecezji poznańskiej (1399), gnieźnieńskiej (14111412; 1423-1436) i krakowskiej (1412-1423). Przebudową wieży katedralnej w Krakowie (obecnie Zygmuntowskicj), rozpoczał starania o wyniesienie królowej Jadwigi na oltarze, dbał o Kapitułę Krakowską i jej dochody. Osadził norbertanów w Krzyżanowicach (1418), wzniósł zamek w Rytwianach. Został pochowany w Beszowej, w kościele, który ufundował (1407) dla paulinów ${ }^{69}$.

Ósmym w pasie południowym jest Ślepowron ${ }^{70}$ herb bpa Franciszka Krasińskiego (10 IV 1525 - 16 III 1577), wspólpracownika Zygmunta II Augusta (1548-1572), szczególnie aktywnego podczas zawierania unii polsko-litewskiej. W 1572 roku zostal mianowany biskupem krakowskim. Sakrę biskupią otrzymal w Warszawie w dniu 6 I 1573 roku, a ingres do katedry odbyl dnia 18 VII 1573 roku. Był zwolennikiem nawracania innowierców „tylko słowem" i odznaczał się tolerancją wobec protestantów ${ }^{71}$.

${ }^{66}$ L. Lętowski, Katalog..., t. 2, s. 144-152; W. Müller, Radziwitt Jerzy. W: PSB, t. 30, s. 229-234; P. Nitecki, Biskupi..., s. 177.

${ }^{67} \mathrm{~W}$ polu błękitnym srebrna podkowa ocelami do góry w niej krzyż kawalerski złoty. S. Górzyński, J. Kochanowski, Herby..., s. 68; J. Szymański, Herbarz ..., s. 138.

${ }^{68}$ L. Lętowski, Katalog..., t. 2, s. 139-144; L. Hajdukiewicz i H. Kowalska, Myszkowski Piotr. W: PSB, t. 22, s. 382-390; P. Nitecki, Biskupi..., s. 146.

${ }^{69}$ L. Letowski, Katalog..., t. 1, s. 338-370; P. Nitecki, Biskupi..., s. 93.

${ }^{70} \mathrm{~W}$ polu blękitnym podkowa srebrna $\mathrm{z}$ takimże zaćwieczonym krzyżem kawaleryjskim, na którym Ślepowron srebrny w lewo (wł. w prawo i niekiedy z pierścieniem zlotym w dziobie). - S. Górzyński, J. Kochanowski, Herby..., s. 147; J. Szymański, Herbarz..., s. $269-270$.

${ }^{71}$ L. Lętowski, Katalog..., t. 2, s. 136-139; W. Urban, Krasinski Franciszek. W: PSB, t. 15, s. 171-173; P. Nitecki, Biskupi..., s. 112-113. 
Kolejnym herbem jest Nowina ${ }^{72}$, rodowy znak Filipa Padniewskiego $(\uparrow 12$ V 1572), który kształcił się na dworze bpa Piotra Tomickiego (1523-1535) w Krakowie i we Włoszech. Znany bardziej jako polityk, dyplomata i humanista niż duchowny. W 1560 roku mianowany biskupem przemyskim, a w dniu 17 VII 1560 rządcą diecezji krakowskiej ${ }^{73}$.

Herb Radwan ${ }^{74}$, który we fryzie zbliżony jest do herbu Ulina ${ }^{75}$ jest znakiem rodowym Andrzeja Zebrzydowskiego (ok. 1500 - 25 V 1560), który studiował w Krakowie, Bazylei, Paryżu i Padwie. Na płaszczyźnie politycznej współpracował z Zygmuntem I Starym (1506-48). Kolejno biskup kamieniecki (od 30 III 1543), chelmski (od 8 VI 1545), kujawsko-pomorski (19 II 1546) i krakowski (od 25 II 1551). W 1558 roku opuścił diecezję oburzony na króla popierającego innowierców ${ }^{76}$.

Ostatnim w pasie poludniowym jest herb Sulima ${ }^{77}$. Jest to herb bpa Piotra Gamrata (1487 - 27 VIII 1545) współpracownika i powiernika królowej Bony (1494-1557). Polityk, administrator i komisarz królewszczyzn na Mazowszu. Przeszedł przez różne stanowiska kościelne: od 1531 roku biskup kamieniecki, następnie przemyski (1535-1537), płocki (1537-1538), krakowski (od 29 VIII 1538) i równolegle (od 28 I 1541) arcypiskup gnieźnieński. Przeciwnik reformacji, organizator urzędu inkwizytora do zwalczania herezji w diecezji krakowskiej (1541), dobry administrator i organizator szkolnictwa. Przeprowadzil synod diecezjalny (1544) oraz prowincjonalny w Piotrkowie Trybunalskim i nałożył na kanoników obowiązek głoszenia kazań. Otaczał opiekł Akademię Krakowska. Miłośnik sztuki, bibliofil, „człowiek odrodzenia" otaczający się licznym dworem ${ }^{78}$.

W pasie zachodnim, podobnie jak we wschodnim, znajduje się pięć herbów. Pierwszym, od strony południowej, jest herb Awdaniec zwany niekiedy

${ }^{72} \mathrm{~W}$ polu blękitnym na zawiasie kotłowej srebrnej barkiem w dól taki sam miecz. S. Górzyński, J. Kochanowski, Herby..., s. 109; J. Szymański, Herbarz..., s. 200.

${ }^{73}$ L. Lętowski, Katalog..., t. 2, s. 129-136; L. Hajdukiewicz i H. Kowalska, Padniewski Filip. W: PSB, t. 25, s. 1-7; P. Nitecki, Biskupi..., s. 158.

${ }^{74} \mathrm{~W}$ polu czerwonym choragiew kościelna złota o trzech strefach $\mathrm{z}$ zaćwieczonym takim samym krzyżykiem kawalerskim. - S. Górzyński, J. Kochanowski, Herby..., s. 134; J. Szymański, Herbarz..., s. 246.

${ }^{75} \mathrm{~W}$ polu majuskularna litera „M” z zaćwieczonym krzyżem łacińskim. - J. Szymański, Herbarz..., s. 282.

${ }^{76}$ L. Lętowski, Katalog..., t. 2, s. 124-129; S. Dobrzanowski, Zebrzydowski Andrzej. W: SPTK, t. 4, s. 536-538; Nitecki, Biskupi..., s. 236.

${ }_{77}$ Tarcza dwudzielna $w$ pas, w polu pierwszym złotym półorzeł czarny, w drugim czerwone trzy kamienie (2+1). - S. Górzyński, J. Kochanowski, Herby..., s. 144; J. Szymański, Herbarz..., s. 263-264.

${ }^{78}$ L. Lętowski, Katalog..., t. 2, s. 105-117; H. Borcz, Gamrat Piotr. W: EK, t. 5 , k. 847-848; P. Nitecki, Biskupi..., s. 62. 
Abdank lub Habdank ${ }^{7 y}$. Herbem tym posługiwał się bp Jan Chojeński (17 III 1486 - 11 III 1538) - wybitny przedstawiciel humanizmu, protektor uczonych i kształcacej się młodzieży. Dbal o podniesienie szpitalnictwa. Kaznodzieja, reformator obyczajów kleru. Uważany za jednego z najgorliwszych bpów w XVI wieku. Od 1523 roku sekretarz królewski, a w trzy lata później sekretarz wielki koronny, $z$ kolei kanclerz wielki koronny (1537). Protegowany Zygmunta I Starego (1506-1548) i królowej Bony (1494-1557). Od 1531 roku biskup przemyski, od 1535 plocki, a od dnia 4 VII 1537 roku krakowski ${ }^{80}$.

Tego samego herbu używał Jan Konarski (1447 - 3 IV 1525), od 1488 roku włodarz dóbr biskupich i marszałek dworu bpa krakowskiego F. Jagiellończyka (1488-1503). Jako proboszcz katedry krakowskiej (od 1497) zostal, w dniu 7 IV 1503 roku, wybrany administratorem diecezji krakowskiej, a wkrótce potem biskupem krakowskim. Sakrę otrzymal w dniu 1 X 1503 roku. Okazał się dobrym administratorem diecezji zarówno w sprawach duszpasterskich jak i majątkowych. Propagator kultu Matki Bożej - w 1509 roku zaprowadził w diecezji święto Poczęcia Najświętszej Maryi Panny. Zainicjował odnowę liturgiczna $w$ diecezji, dbał o podniesienie poziomu naukowego Akademii Krakowskiej. Był pobożny, odznaczal się czcią Eucharystii, troszczył się o katedrę, uchodził za mecenasa sztuki. W dniu 6 IV 1524 roku ustapil z biskupstwa na rzecz swego koadiutora bpa Piotra Tomickiego $(1464-1535)^{81}$.

Następnym jest herb Prawdzic ${ }^{82}$, który to herb używał Jan Latalski ( $\nmid 29$ VIII 1540). Zanim zostal biskupem pelnił wiele funkcji publicznych i kościelnych, m.in. byl notariuszem w konsystorzu poznańskim (1488-91), pisarzem biskupim (od 1492), kanclerzem (1498-1505) królowej Elżbiety Rakuszanki (1436-1505) i sekretarzem (1504-1524) króla Zygmunta I Wazy (15061548). Posiadal wiele beneficjów kościelnych. Mianowany biskupem w dniu 17 V 1525 roku, miesiąc później objął rządy w diecezji poznańskiej. Następnie ordynariusz krakowski (19 V 1536 - 15 IX 1537) oraz arcybiskup gnieźnieński. Popularnie określany jako czlowiek renesansu i mecenas uczonych ${ }^{83}$.

${ }^{79} \mathrm{~W}$ polu czerwonym srebrna łękawica. - S. Górzyński, J. Kochanowski, Herby..., s. 35; J. Szymański, Herbarz..., s. 74

${ }^{80}$ L. Łętowski, Katalog..., t. 2, s. 100-105; J. Bazydło, Chojeński Jan. W: EK, t. 3, k. 210-211; P. Nitecki, Biskupi..., s. 37-38.

${ }^{81}$ L. Lętowski, Katalog..., t. 2, s. 58-74; M. Goetel - Kopffowa, Konarski Jan. W: PSB, t. 14, s. 458-461; P. Nitecki, Biskupi..., s. 106.

${ }^{82} \mathrm{~W}$ polu srebrnym (niekiedy błękitnym) mur czerwony z blankami, zza którego pół lwa złotego w lewo (wł. w prawo) wspiętego z takąż toczenica w lapach. - S. Górzyński, J. Kochanowski, Herby..., s. 127; J. Szymański, Herbarz..., s. 235.

${ }^{83}$ L. Lętowski, Katalog..., t. 2, s. 95-100; I. Sulkowa-Kurasiowa, Latalski Jan. W: PSB, T. 16, s. 562-563; P. Nitecki, Biskupi..., s. 120. 
W części środkowej fryzu zachodniego widnieje herb Lodzia ${ }^{84}$, który to herb używal Piotr Tomicki (1464 - 29 X 1535), który od 1514 roku byl biskupem przemyskim a od 1520 roku także poznańskim. W latach 1523-1524 był koadiutorem bpa krakowskiego Jana Konarskiego (1503-1524); potem ordynariusz od dnia 6 IV 1524 roku. Polityk i dyplomata, podkanclerzy państwa (1515), mecenas kultury i nauki. Skupił wokól siebie uczonych, pisarzy i poetów. Przyozdobił pałac biskupi w Krakowie, wybudował budynki gospodarcze na Biskupim i fundował kolegiatę św. Anny w Krakowie (przed 1535). W okresie jego rządów powstaly Acta Tomiciana - zbiór materiałów historycznych dotyczacych Polski w okresie Odrodzenia ${ }^{85}$.

Kolejnym jest herb Pólkozic ${ }^{86}$ - herb używany przez Jana Rzeszowskiego (1411 - 28 II 1488), który po śmierci bpa Jana Lutka (†21 V 1471) pelnil funkcje administratora diecezji. Biskupem krakowskim został przez kapitułe z polecenia króla Kazimierza Jagiellończyka (1447-1492) w dniu 15 VIII 1471 roku. Wybór ten zatwierdzil Sykstus IV (1471-1484). Sakrę biskupia przyjąl dnia 19 I 1472 roku. Dbał o majątek katedralny, ukończył budowę kaplicy Świętego Krzyża przy katedrze wawelskiej, zbudował skarbiec katedralny, wydał mszał dla diecezji ${ }^{87}$.

Herb Półkozic był również znakiem Pawla z Przemankowa (†29 XI 1292), który został wybrany ordynariuszem krakowskim przez kapitułe jako świecki czlowiek w dniu 9 X 1266 roku, co potwierdził metropolita Janusz (1258-1271). W ciagu dwóch dni otrzymał święcenia kapłańskie i biskupie. Mimo, że jako człowiek świecki był kanclerzem księcia Bolesława Wstydliwego (1243-79), to jako biskup byl w opozycji do niego. W 1273 roku przyłączył się do zbuntowanego rycerstwa małopolskiego, za co znalazł się w książęcym więzieniu. Po raz drugi znalazł się w więzieniu w 1283 roku, kiedy popadł w konflikt z Leszkiem Czarnym (1279-1288) następca Bolesława. Kolejny raz został wtrącony do więzienia przez księcia Henryka Probusa (1288-1290), który po śmierci Leszka Czarnego panował w Krakowie. Był przeciwnikiem wplywów niemieckich w Krakowie, które umocniły się w latach rządów bpa Prandoty (1242-1266). Dla prowadzenia biskupich spraw sądowych ustanowil urząd oficjała ${ }^{88}$.

${ }^{84} \mathrm{~W}$ polu czerwonym zlota lódź. - S. Górzyński, J. Kochanowski, Herby..., s. 101; J. Szymański, Herbarz..., s. 186.

${ }^{85}$ L. Lętowski, Katalog..., t. 2, s. 74-95; P. Nitecki, Biskupi..., s. 210.

${ }^{86} \mathrm{~W}$ polu czerwonym głowa ośla srebrna wprost. - S. Górzyński, J. Kochanowski, Herby..., s. 126; J. Szymański, Herbarz..., s. 227-228.

${ }^{87}$ L. Lętowski, Katalog..., t. 2, s. 32-44; P. Nitecki, Biskupi..., s. 183.

${ }^{88}$ L. Eętowski, Katalog..., t. 1, s. 182-216; J. Wyrozumski, Pawel z Przemankowa. W: $P S B$, t. 25, s. 391-394; P. Nitecki, Biskupi.., s. 161 
Ostatnim z omawianych jest herb Doliwa ${ }^{89}$ używany przez Jana Lutka (ok. 1405 - 24 V 1471). Pracował w dyplomacji królewskiej oraz posiadal różne prebendy kościelne. Uczestniczył w soborze w Bazylei (1434) jako wysłannik króla Władysława Jagiełly (1386-1334). Brał udział w synodzie łęczyckim (1441). Posiadal tytul audytora i kapelana papieża Mikolaja V (1447-1455). W Rzymie dzialał na rzecz Polski w sporze z Krzyżakami. W 1453 roku został administratorem diecezji gnieźnieńskiej, a w dziesięć lat później otrzymał nominację na biskupstwo kujawskie. Sakrę biskupią otrzymał w dniu 7 XI 1463 roku. Rządca diecezji krakowskiej zostal mianowany w dniu 19 X 1464 roku. Pozostawił po sobie obraz mądrego, tolerancyjnego i pobożnego duszpasterza ${ }^{90}$.

Tym samym herbem pieczętował się Piotr Szyrzyk (†6 VI 1348), nazywany niekiedy Falkowskim. Zasiadał w kilku kanoniach oraz był rektorem kościoła w Stopnicy, prepozytem sandomierskim i św. Floriana na Kleparzu. Biskupem krakowskim zostal wybrany przez kapitułe po śmierci bpa Jana Grota (†5 VIII 1347). Zatwierdzenie papieskie uzyskał w dniu 12 XII 1347 roku. Sakrę biskupią otrzymał w lutym 1348 roku w Awinionie; tam też zmarł i zostal pogrzebany ${ }^{91}$.

Ostatnim fragmentem fryzu heraldycznego jest pas umieszczonych na ścianie północnej powyżej okien. Pierwszym od strony zachodniej widnieje herb Poraj ${ }^{92}$, którym pieczętowało się sześciu biskupów. Jan Gruszczyński (1405 - 8 X 1473) zasiadał na stolicy biskupiej w Krakowie tylko piętnaście miesięcy. Wpierw był rządcą diecezji kujawsko-pomorskiej (1450-1462), potem krakowskiej (6 VII 1463 - 19 X 1464) a następnie został mianowany arcybiskupem gnieźnieńskim i prymasem Polski (1464-1473). Był mocno zaangażowany w sprawy polityczne, współpracował z królem Kazimierzem Jagiellończykiem $(1447-1492)^{93}$.

Zawisza pochodzący z Kurozwęk był biskupem krakowskim w latach 1380-1382. Zostawił po sobie pamięć zdolnego i energicznego biskupa. Zmarł w dniu 12 I 1382 roku w Dobrejwodzie k. Wiślicy i pogrzebany zostal w katedrze wawelskiej ${ }^{94}$.

${ }^{89} \mathrm{~W}$ polu błękitnym pas srebrny w lewo skos, na którym trzy róże czerwone. S. Górzyński, J. Kochanowski, Herby..., s. 50; J. Szymański, Herbarz..., s. 112.

${ }^{90}$ L. Eętowski, Katalog.., t. 2, s. 25-32; P. Nitecki, Biskupi..., s. 89

${ }^{91}$ L. Lętowski, Katalog..., t. 1, s. 260-262; F. Kiryk, Piotr z Fałkowa. W: PSB, t. 26, s. 396-397; P. Nitecki, Biskupi..., s. 166; M. D. Kowalski, Prałaci.., s. 243.

${ }^{92} \mathrm{~W}$ polu czerwonym róża pięciopłatkowa srebrna. - S. Górzyński, J. Kochanowski, Herby..., s. 124; J. Szymański, Herbarz..., s. 231-232.

${ }^{93}$ L. Lętowski, Katalog..., t. 2, s. 1-25; K. Malinowski, Gruszczyński Jan. W: PSB, t. 9, s. 55-57; P. Nitecki, Biskupi..., s. 73.

${ }^{94}$ L. Lętowski, Katalog..., t. 1, s. 290-297; A. Strzelecka, Kurozwęcki Zawisza. W: $P S B$, t. 16, s. 277-278; P. Nitecki, Biskupi..., s. 235. 
Innym rządca diecezji krakowskiej, posługujacym sie omawianym herbem był Bodzanta (ok. 1290 - 12 XII 1366) w czerwcu 1348 roku osadzony na biskupstwie krakowskim decyzja Klemensa VI (1342-1352) w miejsce zmarlcgo bpa elekta P. Szyrzyka (†6 VI 1348). Wywolało to sprzeciw Kazimierza Wielkiego (1333-1370), z którym biskup pozostawał w ciąglych konfliktach. Bodzanta był pobożny, pozostawił po sobie pamięć czciciela Najswiętszej Maryi Panny, fundowal liczne altarie i prebendy. Zalożył Bodzentyn i kilka wsi, troszczyl się o dobra kościelne. Ukończył budowę katedry, która w 1364 roku konsekrowal. W tym samym roku nastapiła erekcja akademii przez Urbana V (1362-1370) ${ }^{95}$.

Czwartym z kolei, używającym tegoż znaku ${ }^{96}$, był Wincenty Kadłubck (ok. $1150-8$ III 1223). Wybrany biskupem przez kapitułę krakowską w 1207 roku, co potwierdzil papież Innocenty III (1198-1216) w 1208 roku. Byl to pierwszy biskup wybrany w Polsce przez kapitułe, bral udzial w soborze Laterańskim IV (1213). Autor „Kroniki polskiej”. W 1217 roku otrzymał zgodę papieża Honoriusza III (1216-1227) na rezygnację ze stanowiska ordynariusza i w 1218 roku wstapił do klasztoru cystersów w Jędrzejowie. Po rezygnacji z biskupstwa Iwo Odrowąża papież Honoriusz III przywrócił Wincentego na stolicę biskupia, ale ten nie objął jej gdyż zmarł w Jędrzejowie. Beatyfikowany w 1764 roku przez Klemensa XIII (1758-1769).

Kolejnym, używającym rodowego herbu Poraj był Radost, nazywany także Radostustem (†19 I 1142), wyniesiony na biskupstwo krakowskie w 1118 roku za wola Bolesława Krzywoustego (1102-1138). Radost prowadził rozpoczęta przez swego poprzednika Maurusa (†1117) budowę katcdry wawelskiej ${ }^{97}$.

Najwcześniejszym, któremu przypisuje się herb Poraj jest Lambert $(\uparrow 25$ XI 1101), wyniesiony na biskupstwo w 1082 roku przez księcia czeskiego Wratysława II (1032-1092). Przeprowadzil reorganizację kapituły tworząc urząd dziekana i archidiakona, któremu powierzył funkcję sądowniczą oraz wizytowania duchowieństwa i przygotowania kandydatów do kapłaństwa. Dokończył rozbudowy katedry, którą konsekrowal. W 1088 roku przeniósł relikwie bpa Stanisława ze Skałki na Wawel (jeżeli translacja nie dokonała się w 1150$)^{98}$.

${ }^{95}$ L. Letowski, Katalog..., t. 1, s. 262-278; J. Bazydło, Bodzanta. W: EK, t. 2, k. 703; P. Nitecki, Biskupi..., s. 31; M. D. Kowalski, Prataci..., s. 132.

${ }^{96}$ Nickiedy przypisuje się bł. Wincentemu h. Lodzia.

${ }^{97}$ L. Łętowski, Katalog..., t. 1, s. 57-58; Z. Kozlowska-Budkowa, Radost. W: PSB, t. 29, 747; P. Nitecki, Biskupi..., s. 176.

${ }_{98}$ L. Lętowski, Katalog..., t. 1, s. 46-50; Z. Kozłowska-Budkowa, Lambert. PSB, t. 16, s. 423-424; P. Nitecki, Biskupi..., s. 119. 
Drugım z kolei w pasie północnym, patrząc od strony zachodniej, jest herb Dębno ${ }^{99}$, jest herb, którym pieczętowal się Jakub z Sienna (1413 - 4 X 1480), mianowany biskupem krakowskim przez Piusa II (1458-1464) w dniu 24 XI 1460 roku. Sakrę przyjął w dniu 31 V 1461 roku. Jednak już dnia 7 I 1462 roku zrezygnował z urzędu, z powodu sprzeciwu Kazimierza Jagiellończyka (1447-1492). Od X 1464 roku (ingres 21 III 1465) biskup kujawskopomorski oraz od dnia 10 XII 1573 roku arcybiskup gnieźnicński i prymas ${ }^{100}$.

Tego samego herbu używał kard. Zbigniew Oleśnicki (5 XII 1389 - 1 IV 1455). Został mianowany biskupem krakowskim jako człowiek świecki w dniu 9 VII 1423 roku. Zanim przyjął sakrę biskupią dnia 19 XII 1423 roku, otrzymał święcenia kaplańskie. Jest pierwszy z Polaków obdarzony kapeluszem kardynalskim $\mathrm{m}$. in. fundator paulinów w Pińczowie i bernardynów w Krakowie, dobrodziej Akademii Krakowskiej, budowniczy kościola w Piotrawinie i kolegiaty w Nowym Sączu. W 1443 roku wzbogacil biskupstwo krakowskie zakupionym księstwem siewierskim. Ustanowił i uposażył w katedrze urząd kaznodzici oraz powołal penitencjarzy ${ }^{101}$.

W dalszej kolejności umieszczono herb Prus I zwany również Turzyna ${ }^{102}$, którym jako znakiem rodowym pieczętowal się Tomasz Strzępiński (10 VIII 1398 - 22 IX 1460), profesor i rektor Akademii Krakowskiej, mianowany biskupem w dniu 25 IX 1455 roku, sakrę otrzymal cztery miesiące później. Dyplomata, bibliofil. Gorliwy obrońca moralności i wiary ${ }^{103}$.

Herbem Prus I pieczętowł się również Czasław, który żył na przelomie XI/XII wieku. Okres jego posługi biskupiej przypada pomiędzy śmiercią Lamberta $(\dagger 1101)$ a objęciem rządów diecezją przez Baldwina ok. 1102-1104 roku. Mianowany biskupem przez księcia Władysława I Hermana (10791102), co nie było zgodne z zasadami reformy gregoriańskiej. Zwolennik antypapieża Klemensa III (1080-1100) i być może $z$ tego powodu został usunięty z urzędu zarzadcy diecezji ok. 1102-1104 roku przez Bolesława Krzywoustego $(1102-1138)^{104}$.

${ }^{99} \mathrm{~W}$ polu czerwonym krzyż srebrny z taka samą łękawica pod dolnym lewym ramieniem. - S. Górzyński, J. Kochanowski, Herby..., s. 108-109; J. Szymański, Herbarz..., s. 49 . s. $364-367$

${ }^{100}$ L. Letowski, Katalog..., t. 1, s. 420-435; F. Kiryk, Jakub z Sienna. W: PSB, t. 10 , ${ }^{101}$ L. Lętowski, Katalog..., t. 1, s. 370-408; M. Koczerska, Oleśnicki Zbigniew. W: PSB, t. 23, s. 776-784; P. Nitecki, Biskupi..., s. 154.

${ }^{102} \mathrm{~W}$ polu czerwonym półtora krzyża srebrnego. - S. Górzyński, J. Kochanowski, Herby..., s. 128; J. Szymański, Herbarz .., s. 238; tamże, s. 431-432.

${ }^{103}$ L. Lętowski, Katalog..., t. 1, S. 408-420; S. Dobrzanowski, Strzempiński Tomasz. W: $S P T K$, t. 4, s. 221-223.

${ }^{104}$ L. Lętowski, Katalog..., t. 1, s. 48; R. Grodecki, Czastaw. W: PSB, t. 4, s. 304; P. Nitecki, Biskupi,.., s. 43. 
Omawiany herb przypisywany jest św. Stanislawowi ze Szczepanowa (ok. 1030/1035 - 11 IV 1079). W okresie wyprawy kijowskiej króla Bolesława (1076-1081) biskup popadł z nim w konflikt, który zakończył się zamordowaniem Stanislawa. Tradycja każe dopatrywać się u św. Stanisława troski o ciemiężony i karany przez króla lud. W 1088 lub w 1150 roku dokonano translacji ciała biskupa ze Skalki na Wawel. Po kanonicznym badaniu Innocenty IV (1243-1254) dokonał w dniu 17 IX 1253 roku kanonizacji bpa Stanislawa ${ }^{105}$.

Czwartym z kolei jest herb Leszczyc zwany często Bróg lub Laska ${ }^{106}$. Jest to rodowy herb Piotra z Radolina (Wyszem), który zostal prckonizowany biskupem krakowskim w dniu 19 XII 1392 roku. Wysz byl wspólpracownikiem Jadwigi (1384-1399) i Jagielły (1386-1434). Przeprowadzil kilka synodów prowincjalnych, dbał o dyscyplinę wśród kleru. W 1412 roku zostal przeniesiony na biskupstwo poznańskie. Zmarł dnia 30 IX 1414 roku w Poznaniu $^{107}$.

Następny herb Jelita ${ }^{108}$ - występujący równicż w pasie sufitowym używał bp Florian Mokrski (1305 - 6 II 1380), wybrany biskupem krakowskim przez kapitulę w dniu 2 II 1367 roku po śmierci Bodzanty (†26 XII 1388), co potwierdzil Urban V (1362-1370) dnia 16 VIII 1367 roku $^{109}$.

Nad oknem środkowym znajduje się herb Oksza ${ }^{110}$, który może być utożsamiany z herbem Topór ${ }^{11}$. Herbu „Oksza” używał Nanker (1265/1270 8 IV 1341) ordynariusz krakowski po śmierci bpa Muskaty (†7 II 1320). Na synodzic w 1320 roku opublikowal zbiór statutów dotyczacych służby Bożej i udziclania sakramentów oraz wprowadził święto Bożego Ciała. Dbał o wykształcenie i podniesienie poziomu duchowieństwa oraz o powiększenie terenu diecezji na Spiszu. Był gorliwym i pobożnym duszpasterzem. Po pożarze w 1306 roku rozpoczął odbudowę katedry. Ubiegal się o przyznanie biskupom krakowskim pierwszego miejsca po metropolitach gnieźnieńskich, zgodnie

${ }^{105}$ L. Eętowski, Katalog..., t. 1, s. 29-46; P. Nitecki, Biskupi..., s. 194.

${ }^{106} \mathrm{~W}$ polu czerwonym bróg złoty na słupach srebrnych. - S. Górzyński, J. Kochanowski, Herby..., s. 93; J. Szymański, Herbarz..., s. 170.

${ }^{107}$ L. Lętowski, Katalog..., t. 1, s. 297-309; S. Trawkowski, Piotr z Radolina. W: $P S B$, t. 26, s. $422-428$.

${ }^{108} \mathrm{~W}$ polu czerwonym trzy skrzyżowane kopie złote. - S. Górzyński, J. Kochanowski, Herby..., s. 71; J. Szymański, Herbarz..., s. 143-144.

${ }^{109}$ L. Eętowski, Katalog..., t. 1, s. 278-290; Z. Budkowa, Mokrski Florian. W: PSB, t. 21, s. 600-602; P. Nitecki, Biskupi..., s. 144; M. D. Kowalski, Prałaci.., s. 147.

${ }^{110} \mathrm{~W}$ polu czerwonym srebrna oksza (tj. duży topór na długim drzewcu) w słup. S. Górzyński, J. Kochanowski, Herby..., s. 113; J. Szymański, Herbarz..., s. 206.

${ }^{111}$ W polu czerwonym srebrny topór w słup. - S. Górzyński, J. Kochanowski, Herby..., s. 152; J. Szymański, Herbarz..., s. 277. 
z dawnymi przywilejami. W 1326 roku został przeniesiony na biskupstwo wrocławskie $^{112}$.

Herbem „Topór" pieczętowal się Lambert Sula (†1071). Miał być pierwszym Polakiem na stolicy biskupiej w Krakowie. Biskupem krakowskim zostal z wyboru kapituly, co zatwierdził papicż Aleksander II (1061-1073). Święcenia biskupie przyjąl w 1061 roku. Stanowiska kościelne obsadzał duchownymi pochodzenia polskicgo. Wspólpracowal ze św. Stanisławem ${ }^{113}$.

W dalszej kolejności znajduje się herb Gozdawa ${ }^{114}$, który używał Jan Muskata (ok. 1250 - 7 II 1320). Pod wpływem króla czeskiego Wacława II (1278-1305) zostal wybrany w dniu 21 III 1294 roku przez kapitułę krakowską biskupem. Rządy w diccczji objąl w pol. 1295 roku pelniąc równocześnie obowiazki kapelana rezydujacego w Pradze Waclawa II. Po dojściu do władzy Wladyslawa Łokietka (1260-1333) w 1306 roku został wypc̨dzony z diccezji i przebywał na Śląsku. W 1308 roku został ekskomunikowany przez abpa Jakuba Świnkę (1283-1314), gdyż poparł wójta krakowskicgo Alberta (†1317) w jego buncie przeciwko Lokietkowi, za co książe wtrącił go do więzienia. Dbal o dochody katedry, powiększył majattek biskupstwa. Otrzymał od Wacława II miasto Biecz, które później utracil. Dokonał licznych lokacji na prawie niemicckim. Przyczynil się do rozwoju górnictwa w Sławkowie. Mimo iż był przeciwnikiem księcia Lokietka to bral udział $w$ jego koronacji $w$ dniu 20 I 1320 roku.

Należy zaznaczyć, że istnieją rozbieżności co do herbu bpa Muskaty ( $Z$ pieczęci: poniżej wyobrażenia bpa $w$ dole tarcza podzielona na dwa pola w słup. W jednej trzy ułożone w trójąt korony, a w drugiej częśsi trzy róże lub kulki muszkatolowe; wg J. Dlugosza biskup posługiwal się herbem wyobrażającym 9 żóltych (złotych) lilii w niebieskim polu)

Ósmym z kolei jest herb Korczak ${ }^{115}$ tradycja przypisuje pochodzącemu z Rusi Prokopowi $(\dagger 1295)$. Biskupem krakowskim zostal mianowany w 1292 lub w 1293 roku za poparciem Wladysława Lokietka (1260-1333). Podczas pobytu w Pradze został zmuszony do ukorzenia się przed królem czeskim Wacławem II (1271-1305), królem Polski od 1300 roku i złożenia mu przysięgi wierności ${ }^{116}$.

112 L. Lętowski, Katalog..., t. 1, s. 237-247; J. Szymański, Nanker. W: PSB, t. 22 , s. 513-514; P. Nitecki, Biskupi..., s. 147.

${ }^{113}$ L. Lętowski, Katalog..., t. 1, s. 26-29; Z. Kozlowska-Budkowa, Lambert. W: PSB, t. 16, s. 423; P. Nitecki, Biskupi..., s. 119.

${ }^{114}$ W polu błękitnym srebrna lilia. - S. Górzyński, J. Kochanowski, Herby..., s. 58; J. Szymański, Herbarz..., s. 126-127.

${ }^{115}$ W polu czerwonym trzy srebrne belki, ku dolowi stopniowo krótsze. - S. Górzyński, J. Kochanowski, Herby..., s. 80; J. Szymański, Herbarz.., s. 156.

${ }^{116}$ L. Lętowski, Katalog..., t. 1, s. 216-221; J. Wyrozumski, Prokop. W: PSB, t. 28, s. 483-484; P. Nitecki, Biskupi..., s. 171 . 
Przedostatnim na ścianie północnej jest herb Odrowąż $\dot{z}^{117}$ - rodowy herb Prandoty (1200 - 20 IX 1266). Biskupem został wybrany przez kapitułę katedralna po 15 III 1242 roku. Sakrę przyjąl dnia 25 V 1242 roku. Świątobliwy, gorliwy, pobożny i lubiany przez wiernych. Dnia 8 V 1254 roku bp Prandota „podniósl” doczesne szczątki św. Stanisława i umieścił je w oltarzu na środku katedry. Czczony od XV wieku jako błogosławiony ${ }^{118}$.

Tym samym herbem posługiwał się Iwo Odrowąż, od 1218 roku biskup krakowski. W 1219 roku został przeniesiony do Gniezna po śmierci swego konsekratora abpa Kietlicza ( $† 22$ III 1219), gdzie jednak nie objął urzędu. Powrócił do Krakowa, gdzie pełnił nadal obowiązki ordynariusza. Założył, pierwszy na ziemiach polskich, szpital w Prądniku Białym pod Krakowem. Fundator i dobroczyńca kościolów i klasztorów. W okresie najazdu Konrada Mazowieckiego (1187-1247) na Kraków schronił się na dworze papieża Grzegorza IX (1227-1241) swego przyjaciela $z$ lat studenckich. Zmarł w Borgo w dniu 21 VII 1229 roku i pochowany został w kościele dominikanów w Krakowie. Iwo Odrowąż czczony jest jako błogosławiony ${ }^{119}$.

Omawiany herb używał także Tomasz Teofil Kuliński (12 XII 1823 - 8 I 1907), w latach 1870-1882 wikariusz apostolski części diecezji krakowskiej w Królestwie Polskim z siedzibą w Kielcach. W dniu 23 II I872 roku zostal mianowany biskupem tytularnym Satala. Sakrę biskupia przyjął w Petersburgu dnia 2 IX 1872 roku. W 1883 roku otrzymał nominację na ordynariusza reaktywowanej w dniu 28 XII 1882 roku diecezji kieleckiej (erygowanej 13 VI 1805, zniesionej 30 VI 1818). Znany z pracowitości, gorliwości i pobożności. Troszczył się o duchowieństwo i seminarium duchowne ${ }^{120}$.

Następnym, noszącym nazwę Zabawa ${ }^{121}$, jest herb którego używał Wisław z Kościelca (†15 III 1242). Jako dziekan kapituły wawelskiej został wybrany biskupem krakowskim w 1229 roku. Zatwierdzenie Stolicy Apostolskiej zyskal dwa lata później. Bp Wisław przyczynil się do odnowy katedry i wzrostu dochodów biskupstwa krakowskiego ${ }^{122}$.

${ }^{117} \mathrm{~W}$ polu czerwonym rogacina srebrna w słup u dołu rozłuczona. - S. Górzyński, J. Kochanowski, Herby..., s. 109; J. Szymański, Herbarz..., s. 202.

${ }^{118}$ L. Lętowski, Katalog..., t. 1, s. 144-182; S. Trawkowski, Prędota. W: PSB, t. 28 , s. 447-542; P. Nitecki, Biskupi..., s. 170.

${ }^{119}$ L. Lętowski, Katalog..., t. 1, s. 116-136; P. Nitecki, Biskupi..., s. 84.

${ }^{120}$ Polska encyklopedia szlachecka. T. 7. Warszawa 1937, s. 221; M. Żywczyński, Kulinski Tomasz. W: PSB, t. 16, s. 160; P. Nitecki, Biskupi..., s. 117.

121 Tarcza dwudzielna w slup, pole pierwsze szachowane czerwono - srebrne, pole drugie blękitne. - S. Górzyński, J. Kochanowski, Herby..., s. 161; J. Szymański, Herbarz..., s. 297.

${ }^{122}$ L. Lętowski, Katalog..., t. 1, s. 136-144; P. Nitecki, Biskupi..., s. 223-224. 
Fryz na ścianie północnej zamyka herb Lis ${ }^{123}$, rodowy znak Pełki Lisa (†11 IX 1207). Na przełomie $1185-1186$ roku zostal wybrany biskupem przez kapitułę wawelską. Konsekrowany przez papieża Urbana III (1185-1187) przed dniem 4 II 1186 roku w Weronie. Po śmierci księcia Kazimierza (†4 V 1194) doprowadził do uznania sukcesji jego maloletniego syna Leszka Białego (1186-1227). Zwolennik reform kościelnych i kontaktów ze Stolica Apostolską. Uzyskał dla bpów krakowskich przywilej pierwszeństwa po metropolicie gnieźnieńskim oraz prawo jego konsekrowania. Popierał klasztory, nadawał im uposażenia. W okresie wzrastającego zamętu odegral znaczącą rolę w Polsce. Za jego rząó́w odbyła się m.in. wizyta legata papieskiego Piotra z Kapui, który polecił małżonkom zawierać śluby kościelne, kapłanom zaś nakazal bezżeństwo ${ }^{124}$. Warto dodać, że taką samą figurę heraldyczną ma herb Dąbrowa I.

Po przeanalizowaniu układu herbów we fryzie i przypisaniu im „właścicieli" rodzi się pytanie, dlaczego nie umieszczono znaków rodowych wszystkich biskupów krakowskich mimo, że znano ich prawdziwe bądź fikcyjne wyobrażenia $^{125}$. Autor projektując ciąg fryzowy oparł się zapewne na wykazie sporządzonym przez K. Niesieckiego ${ }^{126}$, gdzie podano wszystkie znaki heraldyczne biskupów krakowskich. Nasuwa się pytanie czy opuszczenie niektórych herbów bylo zamierzone? Rodzi się następne pytanie, a mianowicie, dlaczego H. Uziembło powtórzył ten sam herb? Dlaczego nie zastosował tej metody wobec innych znaków. Prawdopodobnie nie był zobligowany podziałem ścian, gdyż osobiście wykonywał projekt i mógł dowolnie przcprowadzić kompozycję. Inne pytanie dotyczy umieszczenia administratora diecezji Antoniego Gałeckiego pomiędzy ordynariuszami krakowskimi. Nasuwa się jeszcze jedna uwaga. H. Uziembło utożsamil w dwóch przypadkach herby o zbliżonych godłach: herb Cholewa $\mathrm{z}$ herbem Ostoja oraz herb Topór z herbem Oksza. Jest to nieporawne $z$ punktu widzenia sztuki heraldycznej. Ponadto w kilku przypadkach artysta niepoprawnie przedstawil strony heraldyczne godeł. Można przypuszczać, że artysta oparł się na wyobrażeniach przedstawionych przez A. Brücknera w Encyklopedii staropolskiej ${ }^{127}$.

Fryz heraldyczny w sali posiedzeń Kapituły, Krakowskiej należy do ciekawych przykładów sztuki zdobniczej i użytkowej nawiązującej do średniowiecza. Najstarszą tego rodzaju ornamentykę, sięgającą XIV wieku, można

${ }^{123} \mathrm{~W}$ polu czerwonym rogacina srebrna $\mathrm{W}$ słup dwukrotnie przekrzyżowana. S. Górzyński, J. Kochanowski, Herby..., s. 94; J. Szymański, Herbarz..., s. 177-178.

${ }^{124}$ L. Lętowski, Katalog..., t. 1, s. 80-93; J. Bieniek, Pelka. W: PSB, t. 25, s. 574577; P. Nitecki, Biskupi..., s. 162-163.

${ }^{125}$ Por. K. Niesiecki, Herbarz..., t. 1, s. 32-34.

126 Tamże.

${ }^{127}$ A. Brückner, Encyklopedia staropolska. T. 1. Warszawa 1990 (reprint), k. 421-434. 
spotkać w kaplicy św. Jakuba w Lądzie ${ }^{128}$. Zdaniem o. Pawla Sczanieckiego ${ }^{129}$ podobny fryz, malowany lub płaskorzeźbiony, występował prawdopodobnie w opactwie tynieckim. Swiadczą o tym ciagle odkrywane fragmenty malowideł lub resztki kamiennych herbów ${ }^{130}$. W przyszłości należałoby również zwrócić uwagę na podobny do wawelskiego fryz w pałacu biskupim w Kielcach. Jej heraldyczna tematyka dotyczy rycerstwa i właścicieli ziemskich. Kompozycja heraldyczna $\mathrm{H}$. Uziembly, wykonana na początku obecnego stulecia, miała nie tylko cel dekoracyjny. W miejscu tak bardzo nobliwym, poprzez znaki herbowe, upamiętniono rządców diecezji krakowskiej. W wyobrażeniach 41 herbów artysta „ukrył” 65 postaci stosując w kompozycji swój wlasny klucz.

${ }^{128}$ J. Łojko, Fryz heraldyczny z kaplicy klasztornej św. Jakuba w Ladzie nad Warta. „Studia Źródloznawcze”. T. 22: 1977, s. 125-150; J. Szymański, Herbarz średniowiecznego rycerstwa polskiego. Warszawa 1993, s. 14.

${ }^{129}$ Relacja o. P. Sczanieckiego, Tyniec, 3 V 1996.

${ }^{130}$ B. Kwiatkowska-Baster, Z. K. Baster, Tyniec..., s. 72-73. 